•论坛・国家重点保护野生植物专题

\title{
中国野生植物保护管理的政策、法律制度分析和 建议
}

周志华 ${ }^{*}$, 金效华@2

1. 国家林业和草原局野生动植物保护司, 北京 100714; 2. 中国科学院植物研究所系统与进化植物学国家重点实验室, 北京 100093

摘要: 中国是全球生物多样性最丰富的国家之一。最近40年, 中国的植物多样性保护取得了巨大成就, 实施了多项政策和法 律, 尤其是《野生植物保护条例》和《国家重点保护野生植物名录》先后颁布, 奠定了中国植物保护的法律和政策框架, 就 地保护和迁地保护网络基本形成。但与生态文明建设的要求相比, 野生植物保护依然存在许多不足。本文系统回顾了中国野 生植物保护管理的政策和法律制度，从就地保护、迁地保护、开发利用活动管理三方面分析了其优缺点并提出建议; 重点对 修订《野生植物保护条例》进行讨论并提出建议, 包括修订野生植物和人工培植的定义、优化对开发利用活动的管理程序、 加强国际法和国内法的衔接、细化优化罚则等。

关键词: 国家重点保护野生植物; 保护政策; 法律制度; 《野生植物保护条例》; 修订建议

周志华, 金效华 (2021) 中国野生植物保护管理的政策、法律制度分析和建议. 生物多样性, 29, 1583-1590. doi: 10.17520/biods.2021364. Zhou ZH, Jin XH (2021) Analysis and suggestions on policies and regulations on conservation and management of wild plants in China. Biodiversity Science, 29, 1583-1590. doi: 10.17520/biods.2021364.

\section{Analysis and suggestions on policies and regulations on conservation and management of wild plants in China}

\author{
Zhihua Zhou $^{1 *}$, Xiaohua Jin ${ }^{\text {(D)2 }}$ \\ 1 Department of Wildlife Conservation, National Forestry and Grassland Administration, Beijing 100714 \\ 2 State Key Laboratory of Systematic and Evolutionary Botany, Institute of Botany, Chinese Academy of Sciences, Beijing 100093
}

\begin{abstract}
Aims: China is the home to the world's second-richest flora with approximately 36,000-41,000 species of higher plants. Plant conservation has reached great achievements in the last 40 years, especially with the publications of Regulation on Conservation of Wild Plants of China and the List of National Key Protected Wild Plants. These publications were issued by the central government two decades ago and recently have been amended with updates. Many national nature reserves and botanical gardens have been established to protect the national diversity of plant species, which formalized the in situ and ex situ conservation network. However, there are notable gaps between the conservation needs and the legitimate base in the new era of ecological civilization construction. This review surveys the achievements within botanical conservation and illustrates the gaps in policies and regulations on plant conservation in China. Congruently, we propose suggestions for revising the Regulation on Conservation of Wild Plants of China.

Methods: We summarized the current conservation and management policies on wild plants in China and analyzed the central policies and measures from three facets, e.g., in situ conservation, ex situ conservation, and management on exploitation and utilization. The advantages and disadvantages of these policies and regulations have been analyzed and compared with wild animal management. Furthermore, relevant suggestions to revise the Regulation on Conservation of Wild Plants of China have been provided.

Results: Our analyses indicated the revision of Regulation on Conservation of Wild Plants of China needs to be expedited to enhance in situ and ex situ conservation, including revising the definition of the term "wild plants" and “artificial propagation” to improve the management procedure for exploitation, to enhance the connection between
\end{abstract}

收稿日期: 2021-09-09; 接受日期: 2021-12-01

* 通讯作者 Author for correspondence. E-mail: citeszzh@sina.com 
international laws and domestic laws, and to refine the punishment rules.

Key words: national key protected wild plants; conservation policy; Regulation on Conservation of Wild Plants of China; revision suggestion

中国是全球生物多样性最丰富的国家之一，高 等植物约有 36,000-41,000种 (含种下等级), 其中约 18,000种为中国特有种(The Biodiversity Committee of Chinese Academy of Sciences, 2017; Xie et al, 2021)。野生植物资源既为人类提供了粮食、蔬菜、 药材、木材、花卉、氧气等, 又是重要的遗传资源, 还 是文化发展的物质载体和灵感源泉。保护野生植物 资源是人类实现生态安全和资源安全的重要保障。

近 40年来, 中国植物多样性保护取得了巨大成 就, 相关法律和政策不断出台, 法律框架不断完善, 有力支撑了中国的生物多样性保护, 就地保护和迁 地保护网络基本形成。对中国履行《全球植物保护 战略(2011-2020)》进展情况的分析表明, 总计16个 目标中, 中国已完成目标 $75 \%-100 \%$ 的有 6 个, $50 \%-75 \%$ 的 6 个, 另有 4 个已完成目标的 $25 \%-50 \%$, 总体进展良好(任海, 2021)。但近年来, 野生植物保 护工作的挑战不断显现：(1)在日常管理中，管理对 象“野生植物”越来越难以界定, 造成执法困难; (2) 一些亟待保护的物种迟迟无法进入保护名录; (3)部 分濒危物种分布分散, 无法以设立自然保护地的方 式加以保护; (4)无序开发利用野生植物资源的现象 依然存在, 部分野生植物资源被过度使用; (5)《野 生植物保护条例》等的配套法规不足, 许多条款内 容比较泛化, 细节不足, 容易形成“一管就死、一放 就乱” 的怪圈, 如何避免类似的各种怪圈是管理工 作面临的长期挑战; (6)现有的迁地保护机构分散, 物种收集保存和拯救工作缺乏系统性筹划; (7)野生 植物保护的资金投入严重不足, 宣传缺乏力度, 亟 需改善和提高; (8)国际法和国内法衔接不够等。

针对这些问题, 多位学者提出了各种建议和想 法。罗毅波等(2003)回顾了中国兰科植物的保育现 状, 提出了加强研究、确定保护热点、开展迁地保 护和宣传教育等建议; 邢荣华 ${ }^{\circledR}$ 讨论了中国野生植 物保护立法完善的必要性, 提出制定《野生植物保 护法》, 并对部门分工、管理范围、法律责任等提

(1) 邢荣华 (2007) 我国野生植物保护法的完善. 东北林业大学, 硕 士学位论文, 哈尔滨.
出建议; 林龙(2008)提出了提升法律层级、扩大保 护范围、加大处罚力度等建议; 杨文忠等(2015)分 析了极小种群野生植物的概念及其对中国野生植 物保护的影响, 认为这一概念及相关拯救保护工程 的实施具有里程碑意义。这些建议和想法从法律修 订、类群研究、管理实践和系统分析等方面进行讨 论, 很好地推动了我国植物多样性管理制度的改善 和发展。

中国政府高度重视生物多样性保护, 出台了多 部法律和大量政策文件，加入了多个相关国际协定， 近年进一步将生态文明建设纳入基本国策，并在国 际社会率先提出共建地球生命共同体理念。2021年 召开的《生物多样性公约》第15次缔约方大会, 讨 论了《2020年后全球生物多样性框架》, 主要目的 是应对全球生物多样性保护面临的严峻挑战, 重点 之一是如何加强野生植物保护, 力争逆转野生种群 下降、物种绝灭的趋势。因此, 在我国全面加强生 物多样性保护和生态文明建设, 国际社会启动新的 十年保护目标的背景下, 很有必要对我国野生植物 保护的法律法规和政策进行全面系统的回顾、梳理 和分析, 并提出针对性建议。本文从就地保护、迁 地保护及规范利用的管理措施这3个维度系统梳理 分析了中国野生植物保护管理的政策和法律制度, 提出全面改进保护管理工作的建议, 并结合近年来 法律制度暴露的问题缺陷, 重点讨论了《野生植物 保护条例》的修订, 提出了较为具体的修改建议。

\section{中国野生植物保护管理政策和法律制度}

\section{1 就地保护}

\subsection{1 国内法律制度}

中国在 20 世纪 50 年代开始进行就地保护工作, 原林业部制定了《关于天然森林禁伐区(自然保护区) 划定草案》, 陆续建立了鼎湖山、卧龙等自然保护 区；1981年建立第一批国家级风景名胜区、第一个 国家森林公园。在此基础上, 先后颁布了多部涉及 野生植物就地保护的法律法规(国家林业局普及法 律常识办公室, 2001), 包括1985年发布的《森林和 
野生动物类型自然保护区管理办法》、1994年颁布 的《自然保护区条例》(就地保护核心法规)、2006 年颁布的《风景名胜区条例》、1997年颁布的《野 生植物保护条例》、2019年修订的《森林法》等, 对 就地保护地设置原则、珍稀濒危植物保护方法、保 护地内人类活动管理进行阐述, 基本确定了中国植 物多样性就地保护的基本法律框架。此外, 《森林 公园管理办法》《海洋特别保护区管理办法》她 质 遗迹保护管理规定》等部门规章均对保护野生植物 发挥了积极作用。

\subsection{2 国际法律框架}

中国先后加入多个涉及生物多样性保护的国 际公约, 如1981年正式加入 《濒危野生动植物种国 际贸易公约》(CITES), 1985年正式加入 《保护世界 文化和自然遗产公约》(WHC), 1992年正式加入 《关 于特别是作为水禽栖息地的国际重要湿地公约》

(Ramsar Convention, 简称《湿地公约》), 1993年正 式加入 《生物多样性公约》(CBD), 1997年正式加入 《联合国防治荒漠化公约》(UNCCD)等。这些国际 公约组成了中国生物多样性保护的国际合作机制, 部分公约的内容已和中国国内法律或政策衔接。

CBD是国际生物多样性保护合作的核心法律 框架, 从生态系统、物种和基因多样性3个层次推动 保护, 强调保护、可持续利用和遗传资源的惠益分 享三原则, 先后制定了多个指导性目标和战略规划, 如著名的 “爱知目标” 和 《全球植物保护战略》; 2021-2022年CBD正在制定今后10年的保护框架及 植物保护战略。WHC严格限制自然遗产地的开发活 动, 《湿地公约》和《联合国防治荒漠化公约》分 别对湿地和荒漠植物的就地保护发挥了积极作用。 CITES的重点是管控野生动植物国际贸易, 要求对 资源的利用不会导致物种濒危甚至绝灭, 在对野生 种群调查评估的基础上进行可持续利用, 并确保来 源合法。

\subsection{3 重大工程}

2000年以来, 多项生物多样性保护重大工程得 到部署和实施: 如原国家林业局(现国家林业和草 原局)开展的“野生动植物保护和自然保护区建设工 程”, 通过开展旗舰物种保护和自然保护区建设, 带动重要栖息地或原生境保护修复, 有效保护了中 国90\%的陆地生态系统类型、65\%的高等植物群落 和71\%的国家重点保护野生动植物种类(https://poli tics.people.com.cn/n1/2021/1008/c1001-32247150.ht $\mathrm{ml}$ ); 原国家林业局发布的《全国极小种群野生植物 拯救保护工程规划(2011-2015)》有效推动了极小种 群野生植物的保护(杨文忠等, 2015; 张则瑾等, 2018); 2020年, 国家发展和改革委员会(以下简称 发改委)和自然资源部联合发布的《全国重要生态系 统保护和修复重大工程总体规划(2021-2035年)》 (简称《双重规划》), 以国家生态安全战略格局为基 础, 统筹考虑生态系统的完整性、地理单元的连续 性和经济社会发展的可持续性, 涵盖了从寒带、温 带、亚热带到热带的植被类型, 将全面改善中国自 然生态系统, 促进野生植物保护(http://www.forestry. gov.cn/html/main/main_72/202006111834236662850 11/file/20200611183608986247918.pdf)。另外, 中国 实施约 20 年的天然林保护工程、退耕还林还草工 程、约30年的三北防护林工程等, 都是以保护和修 复植被为主要方式, 对野生植物保护起到了不可忽 视的作用。

\subsection{4 自然保护地建设管理}

1949年以来, 林业、农业、环保等部门建立了 不同类型和宗旨的自然保护地。根据2021年1月的 数据, 中国 (港澳台未统计)有各类自然保护地约 1.18 万个, 包括国家级自然保护区 474 个、国家森林 公园906个、国家湿地公园899个、国家风景名胜区 244 个等，占陆域国土面积的 $18 \%$ 、领海的 $4.1 \%$ (http://www.forestry.gov.cn/main/5981/20210216/063 533609649236.html)。所有自然保护地在2018年开始 实现统一管理, 2020年3月启动整合优化, 预计2021 年完成。

2013年, 中国共产党十八届三中全会通过《中 共中央关于全面深化改革若干重大问题的决定》, 提出建立国家公园体制; 2015年, 发改委等印发《建 立国家公园体制试点方案》, 正式启动试点; 2017 年, 中国共产党第十九次全国代表大会提出建立以 国家公园为主体的自然保护地体系; 2019年6月, 中 央办公厅和国务院办公厅正式印发《关于建立以国 家公园为主体的自然保护地体系的指导意见》。东 北虎豹国家公园、大熊猫国家公园等10处体制试点 启动, 先后在总体规划、机构设置、法规建设、自 然资源资产登记、社区共管、特许经营权、地役权 试点等方面开展了大量尝试, 并研究制定总体布局 方案；2020年开展了体制试点全面评估；2021年10 
月宣布正式设立第一批 5 个国家公园。

\section{2 迁地保护}

《野生植物保护条例》《种子法》《林木种质资 源管理办法》《农作物种质资源管理办法》等为迁 地保护提供了法规依据。在活体植株保存方面, 中 国约195个主要植物园开展了以苏铁科、棕桐科、 兰科、木兰科、裸子植物等为代表性的专类资源收 集和广泛收集工作; 到2016年, 收集了来自288科 2,911属的22,104种乡土植物, 分别占中国全部乡土 植物科、属、种的91\%、86\%和65\% (任海, 2021)。 在农作物种质资源保存方面, 中国已建成 1 个长期 种质库、 1 个备份种质库与 10 个中期种质库, 保存了 包括粮食在内的 340 多种农作物的种质资源(任海, 2021)。在野生植物种质资源保存方面, 建成了中国 西南野生生物种质资源库, 目前已保存 10,601 个植 物物种(达我国有花植物物种总数的 $36 \%$ ) 的种子材 料85,046份, 植物离体培养材料2,093种 24,100份, DNA分子材料7,324种65,456份(http://www.genoban k.org/Departments)。制定了《全国林木种质资源调 查收集与保存利用规划(2014-2025年)》, 现有国家 林木种质资源原地、异地保存库161处, 建成国家林 草种质资源设施保存库山东分库、新疆分库, 保存 各类林木种质资源 10 万余份, 保存以牧草为主的草 种质资源6万多份。在野外回归方面, 截至2020年底, 中国科学家已野外回归 206 个物种, 其中 112 个为中 国特有种(http://www.greentimes.com/green/news/dz bh/ysdw/content/2020-12/11/content_471882.htm)。

\section{3 野生植物的开发利用管理制度}

1996年发布的《野生植物保护条例》(以下简称 《条例》)中所保护的野生植物, 是指原生地天然生 长的珍贵植物和原生地天然生长并具有重要经济、 科学研究、文化价值的濒危、稀有植物。除了前文 提到的就地保护和迁地保护措施, 主要建立了以下 制度:

\subsection{1 名录管理制度}

《条例》规定, 野生植物分为国家重点保护野 生植物和地方重点保护野生植物, 国家重点保护野 生植物分为一级和二级。《国家重点保护野生植物 名录》(以下简称《名录》) 由国务院林业、农业主 管部门商环保、建设等部门制定, 报国务院批准公 布。地方重点保护野生植物名录由省级政府制定并 公布。除一些宏观条款外, 《条例》的大多数规定
都是针对《名录》所列物种。

《名录》(第一批)于1999年颁布(http://www. gov.cn/gongbao/content/2000/content_60072.htm), 目前已有 16 个省(自治区、直辖市)颁布了地方名录。 2021年9月，经国务院批准，国家林业和草原局和 农业农村部颁布了新的《名录》, 共455种和40类(约 1,101种)。其中国家一级54种和4类(约126种), 国家 二级401种和36类(约975种) (http://www.forestry.gov. cn/main/5461/20210908/162515850572900.html; 鲁 兆莉等, 2021)。

\subsection{2 资源调查制度}

《条例》规定, 主管部门应定期组织国家和地 方重点保护野生植物资源调查。中国先后组织了两 次全国调查, 其中第二次涉及309种(含变种)。于 2018年启动了野生兰科植物专项调查, 目前已覆盖 $80 \%$ 的省(自治区、直辖市)。遗憾的是, 目前的《条 例》并没有明确提到针对野生植物的监测制度, 只 提到主管部门应当监视、监测环境对国家重点和地 方重点保护植物生长的影响。从管理实践看, 由于 野生植物调查组织复杂、周期长、耗资大、类群特 异性强, 一般 10 年左右才能开展 1 次, 很难及时掌 握野外种群的动态情况, 导致物种信息滞后, 管理 困难。有必要开展科学监测, 及时更新种群动态。

\subsection{3 采集证制度}

《条例》禁止采集国家一级保护野生植物, 因 科学研究、人工培育、文化交流等特殊需要而采集 的, 应当按照管理权限向主管部门或者其授权的机 构申请采集证。采集国家二级植物应向省级主管部 门或者其授权的机构申请采集证。这是避免野生植 物被过度采集的重要手段。

\subsection{4 出售、收购管理制度}

《条例》规定禁止出售、收购国家一级保护野 生植物, 出售、收购国家二级保护野生植物的, 必 须经省级政府主管部门或者其授权的机构批准。这 为可持续利用野生植物提供了制度基础。

\subsection{5 进出口管理制度}

CITES规定(https://cites.org/eng/disc/text.php)进 出口附录I和附录II所列物种需取得进出口证明书, 经海关查验放行。附录涉及中国2,000多个物种, 例 如兰科、苏铁科、红豆杉属(Taxus)、黄亶 属(Dalbergia) 等。中国的《濒危野生动植物进出口管理条例》于 2006年颁布实施, 是与履行CITES密切相关的法规, 
对濒危物种主管部门、核发进出口证明书的条件、 程序、期限、法律责任等做出了规定, 并采取比 CITES更严格的管理措施, 进口CITES附录II物种 和出口国家重点保护野生植物也要求办理证明书。 该法规与CITES相互衔接, 对避免中国野生动植物 的过度国际贸易发挥了积极作用。

《名古屋议定书》提供了遗传资源跨境转移的 国际管理框架, 采用知情同意和惠益公平分享原 则。由于动植物是遗传资源载体, 因此CITES也是 遗传资源进出境的管理工具之一。因中国国内法律 尚不健全, 虽然防止遗传资源流失的原则写进了法 律, 但操作性不强, 遗传资源流失时不易发现, 发 生后难以追责, 生物海盗现象时有发生, 惠益分享 也限于少数案例, 因此需尽快完善法律体系。

\section{现有政策法规存在的主要问题}

目前, 中国的就地和迁地保护都存在一些问题, 如就地保护法规分散、相互矛盾、存在空缺、申报 体系自下而上, 保护地体系亟待优化; 迁地保护系 统性不强、规模不够, 遗传资源管理法律不健全等。 而《条例》作为植物多样性保护的主要依据, 是这 些问题的一个缩影, 亟需修订。主要问题如下:

\section{1 《名录》修订不及时}

《名录》(第一批)公布于1999年, 包括近300 种。此后, 原国家林业局和原农业部曾研究第二批 《名录》, 但进展缓慢。许多野外采挖数量较多、 需严格管理的物种, 甚至许多极度濒危的旗舰物种, 包括兰科植物、景天科红景天属(Rhodiola)植物等都 未列入, 导致保护管理无法可依。此次《名录》修 订有效解决了该问题, 但《条例》尚未建立合理的 《名录》变更机制。

\section{2 开发利用的管理条款较为粗放}

与动物保护管理相比, 《条例》中有关植物保 护工作的措施不多且粗放, 许多条款缺乏细节, 难 以操作(附录1)。植物开发利用管理制度存在几个明 显的缺陷: (1)不涉及加工、运输、利用等贸易环节; (2)没有明确把可持续利用作为批准出售和收购活 动的基本原则, 采集证发放的科学性有待提高; (3) 购买和收购难以区分, 很难执行。另外, 由于野生 植物贸易的复杂和数量巨大, 只有部分物种实现了 对出售和收购活动的管理。

\section{3 处罚条款过于简单}

《条例》对于违法行为的处罚条款过于简单: (1)涉及的违法行为种类不全, 例如没有关于破坏或 污染野生植物原生境、非法加工野生植物的处罚措 施; (2)处罚力度轻, 犯罪成本低; (3)对于危害程度 及其后果没有细化区分, 目前仅两个等级, 也没有 对采伐、采挖、采集叶片、种子、割取树脂等不同 行为进行区别, 而有的采集方式会导致植物死亡, 例如采伐树木、采挖根部、环剥树皮, 有的则不会 导致植物严重损害, 例如采集种子和叶片。这些都 导致在法律执行中存在不科学、不合理、不公平的 现象。

\section{4 缺少野生植物价值评估客观标准}

由于对野生植物的价值没有核定标准, 对野外 仅有几千株、几百株甚至几株的物种, 与尚有百万 甚至千万株的物种不加区别, 不能体现社会危害程 度的差异; 有时所采挖植物尚未交易, 难以确定违 法所得; 有时无法区别物种价值和加工后的产品价 值, 造成量刑时没有合理依据。新《名录》出台后, 许多草本植物列入, 这一问题将更为突出。

\section{5 缺少配套法规}

《条例》出台后, 没有制定与之配套细化的管 理法规, 如二级保护野生植物往往允许一定程度的 利用，但并没有制定采集证管理办法，也没有将可 持续利用原则以适当的方式加以明确。

\section{保护管理建议}

通过多年保护管理实践, 以及多次组织国内学 者、保护团体讨论, 并对多个保护区和管理机构的 调研工作, 我们建议从以下6方面加强野生植物保 护工作, 完善管理制度, 完善后的野生植物管理的 框架体系见图1。

\section{1 加强对野生植物的就地保护}

(1)通过实施《双重规划》, 特别是其中的《自 然保护地建设及野生动植物保护重大工程建设规 划(2021-2035年)》, 强化对野生植物的保护; (2)进 一步完善就地保护网络, 对生物多样性保护空白地 区进行规划和覆盖, 尤其是全球生物多样性关键性 区域、全国生物多样性代表性区域; (3)加大对保护 地外珍稀濒危野生植物原生境保护点(保护小区)的 扶持力度, 这类保护点由于土地性质、地块分散等 原因, 不便纳入自然保护地, 需要系统划定一批保 


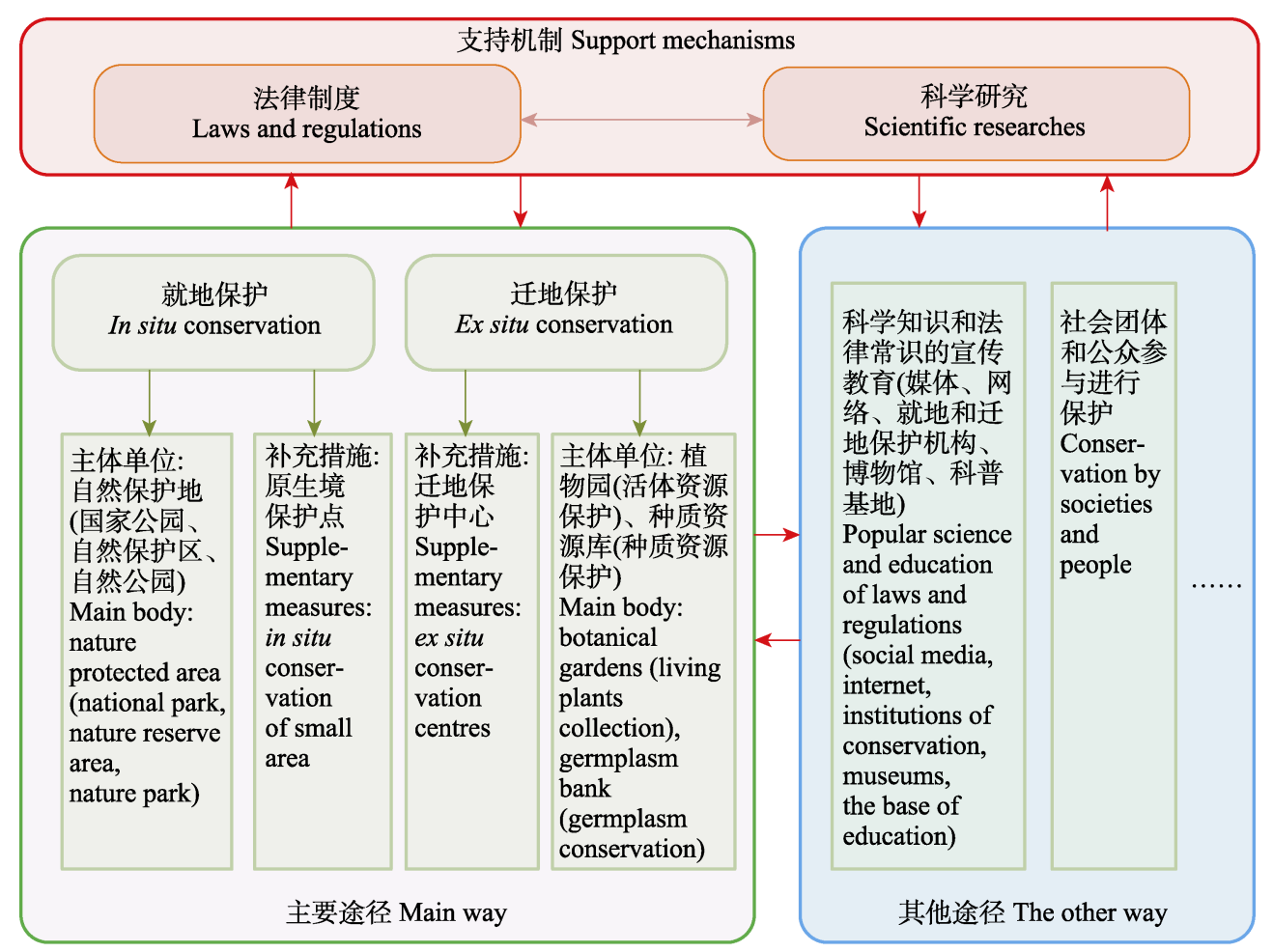

图1 野生植物保护管理框架体系

Fig. 1 Framework of conservation and management system of wild plants

护小区，并通过加大经费支持提升管护水平。

\section{2 加强对野生植物的迁地保护}

(1)完善现有保护设施, 提升科研水平; (2)建设 迁地保护网络, 增加野生植物保存数量和覆盖度; (3)系统建设一批濒危野生植物扩繁和迁地保护研 究中心, 加强重点类群的拯救和野外回归; (4)统筹 种质资源保存工作, 提升规模和水平。要在现有植 物园、树木园、繁育中心、种质资源库等基础上, 分 析迁地保护空缺, 针对现有科研、设施、覆盖度、 气候条件等, 采取挂牌、支持经费、联合建设等方 式进行推动, 制定目标物种清单, 逐步实现中国重 点保护野生植物全覆盖、本土特有植物全覆盖、重 要类群全覆盖等。2021年10月召开的《生物多样性 公约》第15次缔约方大会上, 中国国家主席习近平 提出建立国家植物园体系, 将有效推动迁地保护网 络的强化和完善。可在现有植物园中遴选一些各方 面工作基础较好、具备一定规模和水平的植物园, 通过全面提升野生植物收集保存、科学研究、科普 教育、展示游憩等核心功能, 设立一批国家植物园, 从而构建由国家植物园、植物园(含树木园)、扩繁 和迁地保护中心、种质资源库等共同组成的迁地保
护体系。

\section{3 完善法律制度}

一方面, 加快修订《自然保护区条例》和《风 景名胜区条例》, 出台《自然保护地法》《国家公园 法》《湿地法》等法规, 解决就地保护法规分散、相 互矛盾的问题, 并明确赋予自然保护地管理机构执 法权, 完善就地保护措施。另一方面, 《条例》制 定早, 可操作性不强, 已经无法适应社会发展和保 护需要。2018年, 原国家林业局启动《条例》修订 工作, 开展了多次调研讨论, 各方辩论激烈。作者 根据工作实践和研讨情况, 建议从以下方面完善 《条例》及配套法规。

\subsection{1 修订野生植物的定义}

在司法实践中, 原生地的范围很难界定。建议 将国家或省级主管部门组织的正式野生植物资源 调查确认有分布的县级行政区域作为原生地。另外, 考虑到一些极度濒危或极小种群物种野外回归数 量不大, 但对物种的存续至关重要, 建议将野外回 归种群也纳入野生植物范围加以保护。

\subsection{2 定期修订《名录》}

考虑到社会发展迅速, 应在法律中明确至少每 
五年修订一次名录, 并允许根据具体情况, 及时调 整《名录》, 避免亟待保护的物种迟迟无法保护。

\subsection{3 加强对原生境的管理}

野生植物依赖于其所生存的环境。要明确对其 原生境的保护措施, 如对有毒农药等化学品的使用 管理, 监管基础设施建设、资源采挖、放牧、游览 等人类活动, 要客观评价各种生产经营活动的环境 影响等。目前法律比较模糊, 缺乏可操作性。

\subsection{4 健全利用管理制度}

一方面, 一些物种虽不濒危, 但只有通过有效 管理才能保证资源可持续利用; 还有一些物种为濒 危物种, 但科学研究和育种活动仍需获取少量野生 资源, 需对采集严格管控。另一方面, 一些植物资 源数量允许合理利用一部分, 一旦管理过严就会严 重影响正常的经贸活动, 增加管理和社会成本, 最 终无法落实。《条例》未对这几类情况区别施策。 应考虑从以下方面完善:

(1)修订人工培植的定义。考虑到植物的人工培 植技术已经十分成熟, 建议参考CITES和中国国情, 修改人工培植定义, 明确对合法来源亲本的要求和 控制条件的范围、模式。同时, 简化对来自人工培植 植株的标本的出口管理流程, 统一认定标准和程序。

(2)优化开发利用的管理模式。在借鉴动物管理 对植物开发利用的重要环节进行管制的同时, 不宜 简单套用, 主要原因如下: (i)无论是数量还是币值, 野生植物的贸易量往往都十分巨大, 对物种资源保 护的影响也大得多。例如, 中国2020年度计划的甘 草总采集量为 $90,412.95 \mathrm{t}$, 其中野外采集3,223 t, 人 工培植87,189.95 t。(ii)野生植物利用广泛, 货物类 型极为多样, 且常发生形态改变, 难以鉴别; DNA 条码技术因对DNA样品要求高而很难在各种变形 加工后的材料中应用和普及, 检测成本较高。(iii) 许多植物能人工培植, 但在执法时很难区分人工或 野生来源; 需要开发新的实用的溯源技术进行鉴 定。(iv)野生植物的贸易链条更为复杂, 过严管理意 味着大量的行政资源投入, 也将对经贸活动带来难 以预测的影响。

目前, 可行的办法是参考CITES理念, 重点细 化野生资源采集活动管理。(i)细化对采集证的要求, 严格执行行政许可。(ii)凡允许对野生资源开展一定 规模贸易的物种, 应根据可持续利用原则批准合理 的采集量, 还可制定年度限额。(iii)考虑到极为复杂
的贸易链条和巨大的贸易量, 建议除少数特别珍稀 的物种或例外情况, 不再对市场上的其他销售、加 工、运输、利用等活动使用行政许可, 但可以采取 备案措施, 并要求企业承担尽职调查责任, 留存可 供溯源的依据, 例如合同、发票、文件等, 采用抽 查和违法者重罚的方式, 打击非法贸易活动。(iv) 在进出口环节对野生来源合法性进行严格审核, 同 时简化人工培植成熟的物种的审批程序, 以此平衡 保护需求和有限行政资源的矛盾。

(3)弥补对新贸易模式的管理空白。随着技术进 步, 互联网和自媒体的发展, 新业态、新模式不断 出现。对在互联网上销售野生动植物的行为应加强 监管, 明确政府、买方、卖方、交易平台各自的法 律责任。应当对在互联网上销售行为的取证程序和 证据采用进行规定, 如必要可在《条例》中设定衔 接条款。

\subsection{5 妥善解决国际法与国内法的衔接问题}

(1)建议对于CITES禁止或限制贸易的物种, 首 先由濒危物种管理机构进行分类核定。一方面体现 中国的司法主权, 在国内不直接执行国际法规定; 另一方面可在核定时对违法行为的社会危害程度 进行科学评估。通常CITES附录I物种是因为濒危或 极度濒危, 需要对贸易活动进行禁止或严格限制而 列入; 但附录 II物种的列入原因复杂, 包括几类: 有的是物种濒危, 需对贸易活动管理; 有的是根据 相似性原则, 即该物种与其他附录I或附录II物种十 分相似, 为便于管控后者的贸易而列入; 有的是根 据谨慎原则, 为避免过度的贸易活动导致物种濒危 而列入; 还有的涉及人工繁育或培植的物种。显然 非法贸易的社会危害程度不同, 需区别对待。(2)可 以考虑在极特别情况下, 经国务院批准, 对非原产 中国的CITES附录物种参照本土物种管理。这将为 特殊情况的管理提供法律工具。当然, 这意味着严 格的管控和大量行政成本, 因此, 要严格限制使用。

\subsection{6 细化对违法活动的处罚}

(1)建议对违法行为逐条制定科学合理、易于操 作的处罚规则。(2)制定基于单独物种和不同资源破 坏影响方式造成的价值损失的评估标准, 特别是充 分考虑国家二级保护野生植物和CITES附录II物种 种类繁多, 濒危程度差异较大的实际情况, 应科学 区分不同物种和采集方式, 责罚对应, 甚至可以采 取一个物种一个标准。(3)按照少用刑罚的原则, 参 
考其他国家修订处罚手段, 增加罚金处罚, 减少刑 事处罚。(4)加强事中事后监管, 严厉打击非法采集、 加工、经营、利用、运输的行为。

\section{4 强化科学支撑}

野生植物保护工作有很强的专业性, 要全方位 强化科研机构的参与, 在名录修订、保护地建设管 理、迁地保护机构设立和运行、繁育回归活动的开 展、法律修订、宣传科普等方面充分吸收专家力量, 听取专业意见。鼓励拯救濒危野生植物的科研活 动。应成立国家植物园建设评估专家委员会, 指导 迁地保护工作。

\section{5 鼓励社会参与}

野生植物分布地的民众是最好的保护者, 要寻 求野生植物资源的可持续利用方式, 例如选择当地 有代表性的、具有观赏价值的物种, 发展自然教育、 游息休闲活动, 开发特色文创产品, 通过惠及当地 民众, 促进其主动参与就地保护。要充分推动科研 部门、社会团体和公众参与保护工作, 设计一些容 易参与的项目, 例如开展濒危物种的巡护、监测、 繁育、野外回归等, 从社会筹集资金, 既拓展经费 渠道、扩大保护力量, 也传播保护理念和知识。

\section{6 加强宣传教育}

由于公众对破坏野生植物的行为不如对野生 动物那样敏感, 社会关注度低, 关于植物保护的宣 传教育工作有待强化。应创新方式方法, 充分研究 融媒体时代的传播特点, 借助各类就地和迁地保护 机构、博物馆、科普基地, 以及媒体、网络等, 联 合政府、研究机构、非政府组织和公众的力量, 共 同推动野生植物保护宣传, 强化公众与植物的情感 联系, 广泛使用图片、短视频、形象代言等方式促 进社会公众了解和支持植物保护, 遵守法律法规。

\section{ORCID}

金效华 (D) https://orcid.org/0000-0002-9987-5602

\section{参考文献}

Lin L (2008) Discussion on the deficiencies of legal protection of wild plant resources in China and the countermeasures.
Journal of Northwest A\&F University (Social Science Edition), 8(1), 109-113. (in Chinese with English abstract) [林龙 (2008) 论我国野生植物资源法律保护存在的不足 与对策. 西北农林科技大学(社会科学版), 8(1), 109-113.]

Lu ZL, Qin HN, Jin XH, Zhang ZX, Yang QW, Hong DY, Li DZ, Li KF, Yuan LC, Zhou ZH (2021) On the necessity, principle, and process of updating the List of National Key Protected Wild Plants. Biodiversity Science, 29, 1577-1582. (in Chinese with English abstract) [鲁兆莉, 覃海宁, 金效 华, 张志翔, 杨庆文, 洪德元, 李德铢, 李开凡, 袁良琛, 周志华 (2021) 《国家重点保护野生植物名录》调整的必 要性、原则和程序. 生物多样性, 29, 1577-1582.]

Luo YB, Wang CL, Jia JS (2003) A general review of the conservation status of Chinese orchids. Biodiversity Science, 11, 70-77. (in Chinese with English abstract) [罗毅 波, 王春玲, 贾建生 (2003) 中国兰科植物的保育现状和 展望. 生物多样性, 11, 70-77.]

Popularization Office of Common Law Knowledge, State Forestry Administration (2001) Law Knowledge Book for Forestry Staffs in China. Higher Education Press, Beijing. (in Chinese) [国家林业局普及法律常识办公室 (2001) 全 国林业职工法律知识读本. 高等教育出版社, 北京.]

Ren H (2021) Progress of Implementation on the Global Strategy for Plant Conservation (2011-2020) in China. Science Press, Beijing. (in Chinese and in English) [任海 (2021) 中国履行《全球植物保护战略(2011-2020)》进展 报告. 科学出版社, 北京.]

The Biodiversity Committee of Chinese Academy of Sciences (2017) Catalogue of Life China: 2017 Annual Checklist. Beijing.

Yang WZ, Xiang ZY, Zhang SS, Kang HM, Shi FQ (2015) Plant species with extremely small populations (PSESP) and their significance in China's national plant conservation strategy. Biodiversity Science, 23, 419-425. (in Chinese with English abstract) [杨文忠, 向振勇, 张珊珊, 康洪 梅, 史富强 (2015) 极小种群野生植物的概念及其对我 国野生植物保护的影响. 生物多样性, 23, 419-425.]

Xie D, Liu B, Zhao LN, Pandey TR, Liu HY, Shan ZJ, Qin HN (2021) Diversity of higher plants in China. Journal of Systematics and Evolution, 59, 1111-1123.

Zhang ZJ, Guo YP, He JS, Tang ZY (2018) Conservation status of wild plant species with extremely small populations in China. Biodiversity Science, 26, 572-577. (in Chinese with English abstract) [张则瑾, 郭炎培, 贺金生, 唐志尧 (2018) 中国极小种群野生植物的保护现状评估. 生物多 样性, 26, 572-577.]

(责任编委: 严岳鸿 责任编辑: 黄祥忠)

\section{附录 Supplementary Material}

附录1 我国野生植物和野生动物保护管理制度对比

Appendix 1 Comparison of management rules between wild plants and wild animals https://www.biodiversity-science.net/fileup/PDF/2021364-1.pdf 
附录 1 我国野生植物和野生动物保护管理制度对比

2 Appendix 1 Comparison of management rules between wild plants and wild animals

\begin{tabular}{|c|c|c|c|}
\hline $\begin{array}{l}\text { 制度名称 } \\
\text { Regulation }\end{array}$ & $\begin{array}{l}\text { 野生植物管理相关规定 } \\
\text { Relevant rules on wild plants management }\end{array}$ & $\begin{array}{l}\text { 野生动物管理相关规定 } \\
\text { Relevant rules on wild animals management }\end{array}$ & $\begin{array}{l}\text { 差异比较 } \\
\text { Comparing of } \\
\text { Difference }\end{array}$ \\
\hline $\begin{array}{l}\text { 法律法规 } \\
\text { 名称 }\end{array}$ & $\begin{array}{l}\text { 《野生植物保护条例》 } \\
\text { (https://www.forestry.gov.cn/main/3950/20170314/459881.html) }\end{array}$ & $\begin{array}{l}\text { 《野生动物保护法》 (http://www.npc.gov.cn/npc/c238/202001/a0d85c00a9a44b7a80fd88f2bb678253.shtml) } \\
\text { 《陆生野生动物保护条例》 (http://www.forestry.gov.cn/main/3950/content-459885.html) } \\
\text { 《水生野生动物保护条例》(http://www.gov.cn/gongbao/content/2014/content_2695332.htm) } \\
\text { 及配套法规 }\end{array}$ & $\begin{array}{l}\text { 野生植物保护相关 } \\
\text { 法规的层级不高 }\end{array}$ \\
\hline $\begin{array}{l}\text { 原则或方 } \\
\text { 针 }\end{array}$ & 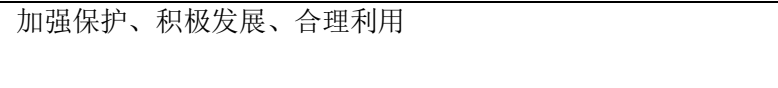 & $\begin{array}{l}\text { 保护优先、规范利用、严格监管 } \\
\text { (http://www.forestry.gov.cn/main/3957/content-945973.html) }\end{array}$ & $\begin{array}{l}\text { 对野生植物的利用 } \\
\text { 原则较为宽松 }\end{array}$ \\
\hline 管理对象 & $\begin{array}{l}\text { 第二条 本条例所保护的野生植物, 是指原生地天然生长的珍贵 } \\
\text { 植物和原生地天然生长并具有重要经济、科学研究、文化价值 } \\
\text { 的濒危、稀有植物。 }\end{array}$ & $\begin{array}{l}\text { 《野生动物保护法》第二条 本法规定保护的野生动物, 是指珍贵、濒危的陆生、水生野生动物和有重要 } \\
\text { 生态、科学、社会价值的陆生野生动物。 } \\
\text { 本法规定的野生动物及其制品, 是指野生动物的整体(含卵、蛋)、部分及其衍生物。 }\end{array}$ & $\begin{array}{l}\text { 对野生和人工繁育 } \\
\text { 来源的野生动物都 } \\
\text { 进行管理, 但只对 } \\
\text { 野生来源的植物进 } \\
\text { 行管理。 }\end{array}$ \\
\hline $\begin{array}{l}\text { 野外猎捕/ } \\
\text { 采集制度 }\end{array}$ & $\begin{array}{l}\text { 第十六条 禁止采集国家一级保护野生植物。因科学研究、人 } \\
\text { 工培育、文化交流等特殊需要, 采集国家一级保护野生植物的, } \\
\text { 应当按照管理权限向国务院林业行政主管部门或者其授权的机 } \\
\text { 构申请采集证; 或者向采集地的省、自治区、直辖市人民政府 } \\
\text { 农业行政主管部门或者其授权的机构申请采集证。 } \\
\text { 采集国家二级保护野生植物的, 必须经采集地的县级人民政府 } \\
\text { 野生植物行政主管部门签署意见后, 向省、自治区、直辖市人 } \\
\text { 民政府野生植物行政主管部门或者其授权的机构申请集证。 } \\
\text { 第十七条 采集国家重点保护野生植物的单位和个人, 必须按照 } \\
\text { 采集证规定的种类、数量、期限和方法进行采集。 }\end{array}$ & $\begin{array}{l}\text { 《野生动物保护法》第二十一条 禁止猎捕、杀害国家重点保护野生动物。因科学研究、种群调控、疫源 } \\
\text { 疫病监测或者其他特殊情况, 需要猎捕国家一级保护野生动物的, 应当向国务院野生动物保护主管部门申 } \\
\text { 请特许猎捕证; 需要猎捕国家二级保护野生动物的, 应当向省、自治区、直辖市人民政府野生动物保护 } \\
\text { 主管部门申请特许猪捕证。 } \\
\text { 猎捕非国家重点保护野生动物的, 应当依法取得县级以上地方人民政府野生动物保护主管部门核发的狩 } \\
\text { 猎证, 并且服从猎捕量限额管理。 } \\
\text { 《野生动物保护法》第二十三条猎捕者应当按照特许猎捕证、狩猎证规定的种类、数量、地点、工具、 } \\
\text { 方法和期限进行猎捕。 }\end{array}$ & $\begin{array}{l}\text { 法律规定的详细程 } \\
\text { 度相似。一级保护 } \\
\text { 物种原则上禁止猎 } \\
\text { 捕或采集, 特例可 } \\
\text { 利用。二级保护物 } \\
\text { 种有限利用。 } \\
\text { 对植物的管理更宽 } \\
\text { 松:一是非国家重 } \\
\text { 点保护野生动物的 } \\
\text { 猎捕也受到管理, } \\
\text { 二是野生植物保护 } \\
\text { 物种的管理向下授 } \\
\text { 权更多。 }\end{array}$ \\
\hline $\begin{array}{l}\text { 人工繁育 } \\
\text { /培植管理 } \\
\text { 制度 }\end{array}$ & 无管理规定(所需野生种源按野外采集管理)。 & $\begin{array}{l}\text { 《野生动物保护法》第二十五条 国家支持有关科学研究机构因物种保护目的人工繁育国家重点保护野生 } \\
\text { 动物。 } \\
\text { 前款规定以外的人工繁育国家重点保护野生动物实行许可制度。人工繁育国家重点保护野生动物的, 应 } \\
\text { 当经省、自治区、直辖市人民政府野生动物保护主管部门批准, 取得人工繁育许可证, 但国务院对批准机 } \\
\text { 关另有规定的除外。 } \\
\text { 人工繁育国家重点保护野生动物应当使用人工繁育子代种源, 建立物种系谱、繁育档案和个体数据。因 } \\
\text { 物种保护目的确需采用野外种源的, 适用本法第二十一条和第二十三条的规定。 }\end{array}$ & $\begin{array}{l}\text { 对野生动物的人工 } \\
\text { 繁育管理严格, 实 } \\
\text { 行许可证制度; 对 } \\
\text { 野生植物人工培植 } \\
\text { 无管理。 }\end{array}$ \\
\hline
\end{tabular}




\begin{tabular}{|c|c|c|c|}
\hline $\begin{array}{l}\text { 制度名称 } \\
\text { Regulation }\end{array}$ & $\begin{array}{l}\text { 野生植物管理相关规定 } \\
\text { Relevant rules on wild plants management }\end{array}$ & $\begin{array}{l}\text { 野生动物管理相关规定 } \\
\text { Relevant rules on wild animals management }\end{array}$ & $\begin{array}{l}\text { 差异比较 } \\
\text { Comparing of } \\
\text { Difference }\end{array}$ \\
\hline $\begin{array}{l}\text { 经营利用 } \\
\text { 管理制度 }\end{array}$ & $\begin{array}{l}\text { 第十八条 禁止出售、收购国家一级保护野生植物。出售、收 } \\
\text { 购国家二级保护野生植物的, 必须经省、自治区、直辖市人民 } \\
\text { 政府野生植物行政主管部门或者其授权的机构批准。 } \\
\text { 第十九条 野生植物行政主管部门应当对经营利用国家二级保 } \\
\text { 护野生植物的活动进行监管。 }\end{array}$ & 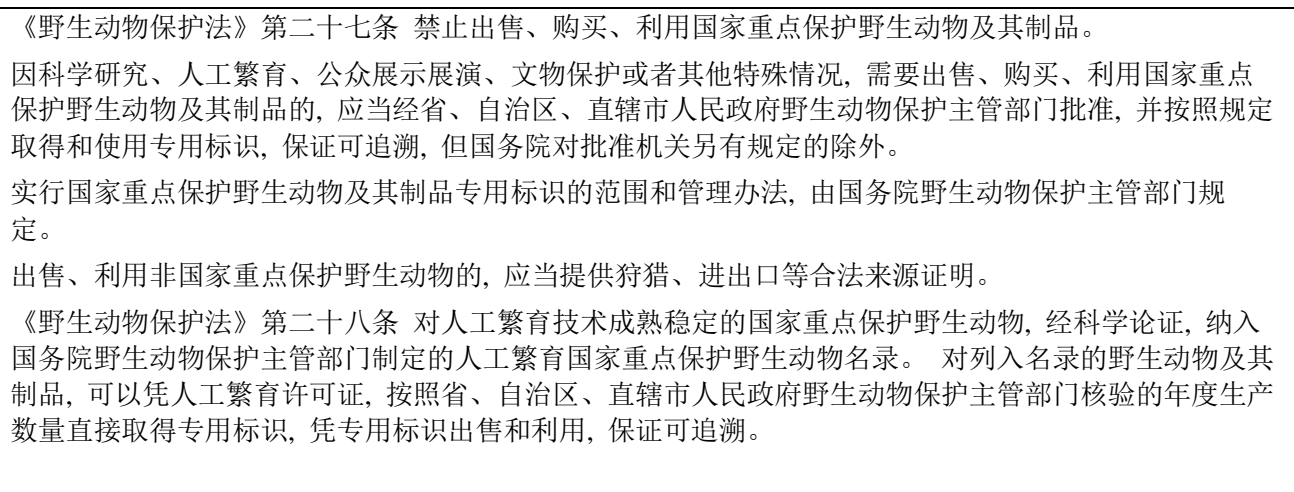 & $\begin{array}{l}\text { 从管理环节看, 对 } \\
\text { 野生动物实行全链 } \\
\text { 条管理, 并建立了 } \\
\text { 标识制度。对非重 } \\
\text { 点保护野生动物也 } \\
\text { 要求提供合法来源 } \\
\text { 证明。 } \\
\text { 对野生植物的管理 } \\
\text { 主要是管理出售和 } \\
\text { 收购, 但经营利用 } \\
\text { 与以上行为的边界 } \\
\text { 不清。措施较为含 } \\
\text { 糊。 }\end{array}$ \\
\hline $\begin{array}{l}\text { 运输管理 } \\
\text { 制度 }\end{array}$ & 无管理规定。 & $\begin{array}{l}\text { 《野生动物保护法》第三十三条 运输、携带、寄递国家重点保护野生动物及其制品、本法第二十八条第 } \\
\text { 二款规定的野生动物及其制品出县境的, 应当持有或者附有本法第二十一条、第二十五条、第二十七条 } \\
\text { 或者第二十八条规定的许可证、批准文件的副本或者专用标识, 以及检证明。 } \\
\text { 运输非国家重点保护野生动物出县境的, 应当持有狩猎、进出口等合法来源证明, 以及检疫证明。 }\end{array}$ & $\begin{array}{l}\text { 野生动物的运输管 } \\
\text { 理规则明确, 并与 } \\
\text { 标识制度关联。野 } \\
\text { 生植物的运输管理 } \\
\text { 无规定。 }\end{array}$ \\
\hline $\begin{array}{l}\text { 进出口管 } \\
\text { 理 }\end{array}$ & 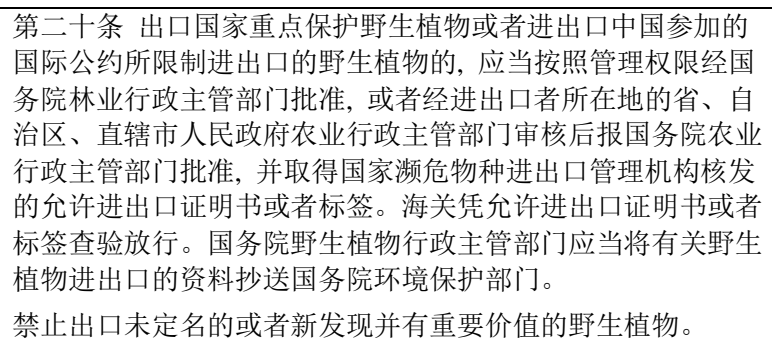 & $\begin{array}{l}\text { 《野生动物保护法》第三十五条 中华人民共和国缔结或者参加的国际公约禁止或者限制贸易的野生动物 } \\
\text { 或者其制品名录, 由国家濒危物种进出口管理机构制定、调整并公布。 } \\
\text { 进出口列入前款名录的野生动物或者其制品的, 出口国家重点保护野生动物或者其制品的, 应当经国务院 } \\
\text { 野生动物保护主管部门或者国务院批准, 并取得国家濒危物种进出口管理机构核发的允许进出口证明 } \\
\text { 书。依法实施进出境检疫。海关凭允许进出口证明书、检疫证明按照规定办理通关手续。 } \\
\text { 涉及科学技术保密的野生动物物种的出口, 按照国务院有关规定办理。 }\end{array}$ & $\begin{array}{l}\text { 进出口管理流程相 } \\
\text { 似。但国际公约限 } \\
\text { 制进出口的野生动 } \\
\text { 物名录, 须经过管 } \\
\text { 理机构的认定, 而 } \\
\text { 对野生植物没有核 } \\
\text { 准认定程序。 }\end{array}$ \\
\hline $\begin{array}{l}\text { 非原产我 } \\
\text { 国物种参 } \\
\text { 照国家保 } \\
\text { 护管理 }\end{array}$ & 无。 & $\begin{array}{l}\text { 《野生动物保护法》第三十五条 列入本条第一款名录的野生动物, 经国务院野生动物保护主管部门核准, } \\
\text { 在本法适用范围内可以按照国家重点保护的野生动物管理。 }\end{array}$ & $\begin{array}{l}\text { 非原产我国的野生 } \\
\text { 动物, 可以核准后 } \\
\text { 按国家重点保护物 } \\
\text { 种进行管理, 但目 } \\
\text { 前被核准的物种数 } \\
\text { 量过多, 有的级别 } \\
\text { 偏高, 使得一些案 } \\
\text { 件量刑偏重。 }\end{array}$ \\
\hline
\end{tabular}




\begin{tabular}{|c|c|c|c|}
\hline $\begin{array}{l}\text { 制度名称 } \\
\text { Regulation }\end{array}$ & $\begin{array}{l}\text { 野生植物管理相关规定 } \\
\text { Relevant rules on wild plants management }\end{array}$ & $\begin{array}{l}\text { 野生动物管理相关规定 } \\
\text { Relevant rules on wild animals management }\end{array}$ & $\begin{array}{l}\text { 差异比较 } \\
\text { Comparing of } \\
\text { Difference }\end{array}$ \\
\hline & & & $\begin{array}{l}\text { 非原产我国的野生 } \\
\text { 植物进口后, 无管 } \\
\text { 理依据。 }\end{array}$ \\
\hline 食用管理 & 无限制。 & $\begin{array}{l}\text { 十三届全国人大常委会第十六次会议于 } 2020 \text { 年 } 2 \text { 月 } 24 \text { 日通过了《全国人民代表大会常务委员会关于 } \\
\text { 全面禁止非法野生动物交易、革除滥食野生动物陃习、切实保障人民群众生命健康安全的决定》, 陆生 } \\
\text { 野生动物基本禁止食用。 } \\
\text { (http://www.np.gov.cn/npc/c30834/202002/c56b129850aa42acb584cf01ebb68ea4.shtml) }\end{array}$ & $\begin{array}{l}\text { 对野生动物极为严 } \\
\text { 格 }\end{array}$ \\
\hline $\begin{array}{l}\text { 价值评估 } \\
\text { 规范 }\end{array}$ & 无。 & $\begin{array}{l}\text { 国家林业局 } 2017 \text { 年第 } 46 \text { 号令《野生动物及其制品价值评估方法》, 设立了物种的基准值, 原则上国 } \\
\text { 家一级物种是基准值的十倍, 国家二级是基准值的五倍。 }\end{array}$ & $\begin{array}{l}\text { 因缺乏价值评估规 } \\
\text { 范, 对涉及野生植 } \\
\text { 物的犯罪量刑存在 } \\
\text { 较大差异。 }\end{array}$ \\
\hline $\begin{array}{l}\text { 立案和量 } \\
\text { 刑标准 }\end{array}$ & 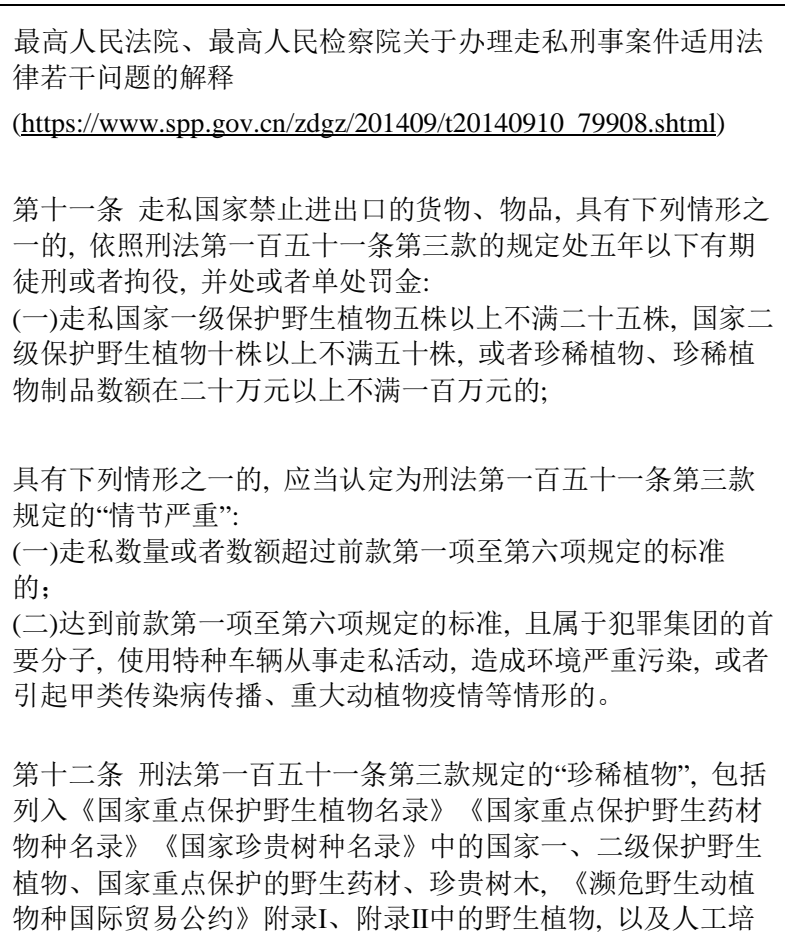 & 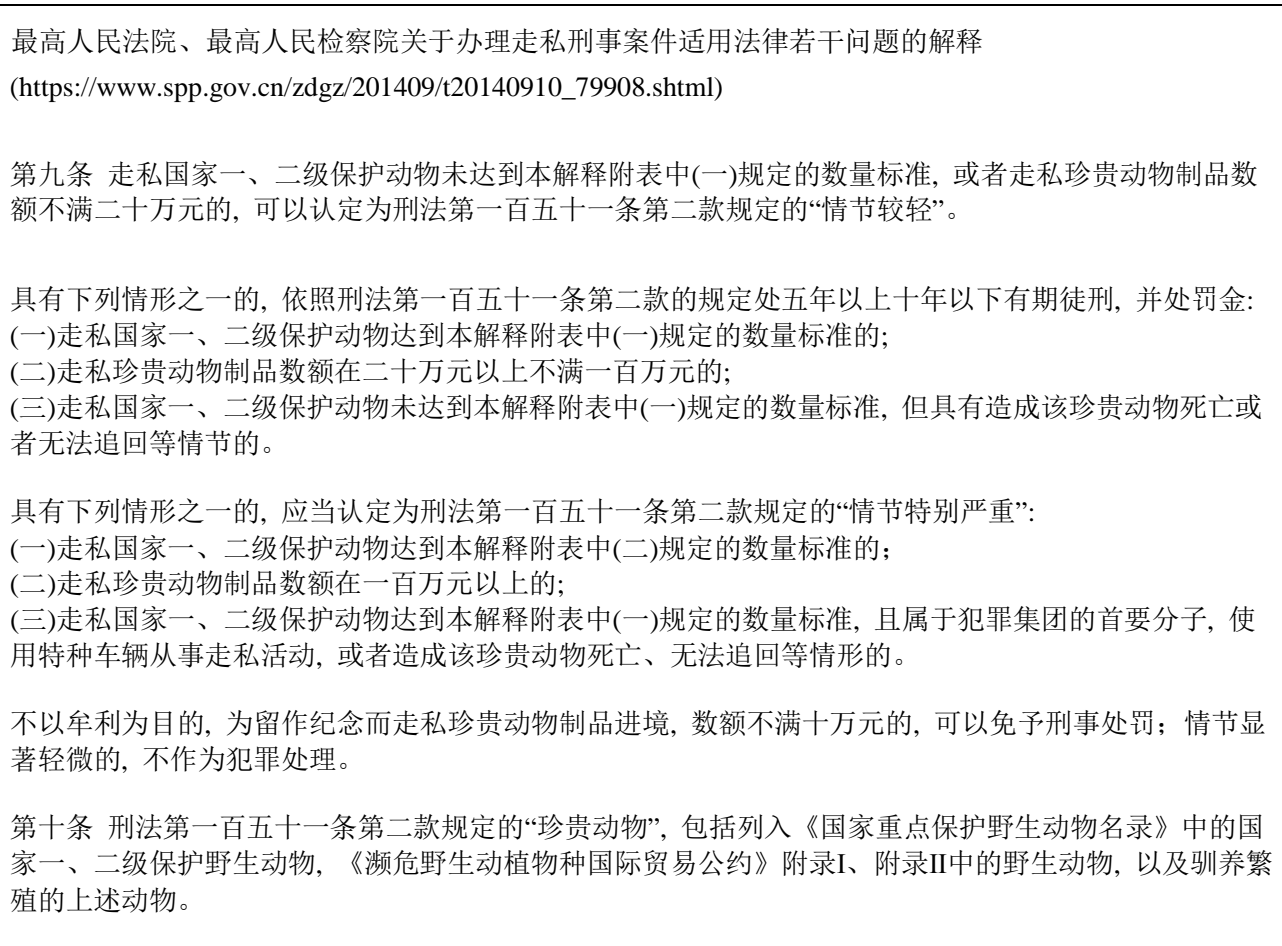 & $\begin{array}{l}\text { 对野生动物走私活 } \\
\text { 动分为轻微、情节 } \\
\text { 较轻、严重、特别 } \\
\text { 严重等几档。附有 } \\
\text { 具体的物种列表。 } \\
\text { 走私驯养繁殖的野 } \\
\text { 生动物也在处罚范 } \\
\text { 围内。 } \\
\text { 对野生植物的走私 } \\
\text { 处罚分为两档, 没 } \\
\text { 有根据物种制定的 } \\
\text { 详细列表。虽然提 } \\
\text { 到人工培植的植物, } \\
\text { 但这里人工培植主 } \\
\text { 要指《濒危野生动 } \\
\text { 植物种国际贸易公 } \\
\text { 约》所涉及的物 } \\
\text { 种。 } \\
\text { 《国家重点保护野 } \\
\text { 生药材物种名录》 } \\
\text { 物种较少, 且陈 } \\
\text { 旧。 } \\
\text { 《国家珍贵树种名 } \\
\text { 录》从未出台, 且 }\end{array}$ \\
\hline
\end{tabular}




\begin{tabular}{|c|c|c|c|}
\hline $\begin{array}{l}\text { 制度名称 } \\
\text { Regulation }\end{array}$ & $\begin{array}{l}\text { 野生植物管理相关规定 } \\
\text { Relevant rules on wild plants management }\end{array}$ & $\begin{array}{l}\text { 野生动物管理相关规定 } \\
\text { Relevant rules on wild animals management }\end{array}$ & $\begin{array}{l}\text { 差异比较 } \\
\text { Comparing of } \\
\text { Difference }\end{array}$ \\
\hline & 育的上述植物。 & $\begin{array}{l}\text { 走私本解释附表中未规定的珍贵动物的, 参照附表中规定的同属或者同科动物的数量标准执行。 } \\
\text { 走私本解释附表中未规定珍贵动物的制品的, 按照《最高人民法院、最高人民检察院、国家林业局、公 } \\
\text { 安部、海关总署于破坏野生动物资源刑事案件中涉及的 CITES 附录I和附录II所列陆生野生动物制品价 } \\
\text { 值核定问题的通知》(林濒发 (2012) } 239 \text { 号)的有关规定核定价值。 }\end{array}$ & $\begin{array}{l}\text { 新的《森林法》删 } \\
\text { 除了这一表述。 }\end{array}$ \\
\hline
\end{tabular}

